\title{
HUBUNGAN KARAKTERISTIK KONSUMEN DENGAN KESEDIAAN MEMBAYAR (WILLINGNESS TO PAY) TERHADAP KENAIKAN HARGA BERAS DI KOTA SUNGAI PENUH
}

\author{
Resti Novitasari ${ }^{1)}$ Adlaida Malik ${ }^{2)}$ dan Dewi Sri Nurchaini ${ }^{2)}$ \\ 1) Alumni Jurusan/Program Studi Agribisnis Fakultas Pertanian Universitas Jambi, \\ 2) Dosen Jurusan/Program Studi Agribisnis Fakultas Pertanian Universitas Jambi \\ Email : restynovitasari462@yahoo.com
}

\begin{abstract}
ABSTRAK
Beras merupakan makanan pokok masyarakat di Kota Sungai Penuh dimana harga beras selalu mengalami kenaikan setiap tahunnya dan membuat konsumen harus bersedia membayar terhadap jenis beras yang dikonsumsinya. Penelitian ini bertujuan untuk (1) mengkaji karakteristik konsumen beras di Kota Sungai Penuh, (2) mengetahui jumlah responden yang bersedia membayar terhadap kenaikan harga beras di Kota Sungai Penuh, dan (3) menganalisis hubungan antara karakteristik konsumen beras dengan kesediaan membayar (WTP) di Kota Sungai Penuh. Penelitian ini dimulai pada tanggal 10 Mei sampai 10 Juni 2016 terhadap 71 konsumen. Metode yang digunakan adalah analisis deskriptif untuk memperoleh gambaran karakteristik konsumen beras di Kota Sungai Penuh dan kesediaan membayar (WTP) konsumen terhadap kenaikan harga beras. Uji Chi-Square digunakan untuk mengetahui hubungan antara karakteristik konsumen dengan kesediaan membayar (WTP) konsumen di Kota Sungai Penuh.

Hasil analisis deskriptif menunjukkan bahwa karakteristik konsumen terdiri dari mayoritas responden memiliki tingkat pendapatan keluarga per bulan sebesar Rp. 900.000 - Rp. 3.590.140, tingkat pendidikan SMA, kelompok usia 34 - 41 tahun dan jumlah anggota keluarga $3-4$ orang. Untuk kesediaan membayar konsumen terhadap kenaikan harga beras yaitu mayoritas responden bersedia membayar sebesar $20 \%$ dari harga sebenarnya dan diperoleh bahwa pendapatan, pendidikan, dan usia memiliki hubungan yang kuat terhadap kesediaan membayar dimana hasil dari $\chi^{2}$ hit $>\chi_{\text {tabel }}^{2}$ keputusannya tolak $\mathrm{H}_{0}$, sedangkan untuk jumlah anggota keluarga tidak memiliki hubungan terhadap kesediaan membayar karena hasil $\chi^{2}$ hit $>\chi^{2}$ tabel sehingga keputusannya terima $\mathrm{H}_{0}$, menunjukkan bahwa semakin tinggi tingkat pendapatan, pendidikan, dan usia konsumen maka semakin tinggi konsumen bersedia membayar terhadap kenaikan harga beras.
\end{abstract}

\section{Kata Kunci : Karakteristik Konsumen, Kesediaan Membayar, Hubungan.}

\section{ABSTRACT}

Rice is a stapple food of the society in Sungai Penuh City, where the price of rice increases every year and makes the consumer should be willing to pay based on the type of rice consumed. This study aims to (1) examine the characteristics of consumers of rice in Sungai Penuh City, (2) the number of respondents who are willing to pay the increase of the rice prices in Sungai Penuh City, and (3) analyze the relationship between characteristics of consumers of rice with a willingness to pay (WTP) in Sungai Penuh City. This study was conducted on 10 May until 10 June 2016 with the number of samples of 71 consumers. The method used in this research is descriptive analysis to obtain an overview of the characteristics of consumers of rice in Sungai Penuh City and acquire of willingness to pay (WTP) of consumers against price increases of rice. Chi-Square test is used to determine the relationship between characteristics of consumer and willingness to pay (WTP) of consumersin Sungai Penuh City.

Descriptive analysis shows that consumer characteristics consists of majority of the respondents had a monthly family income level of Rp. 900.000 - Rp. 3.590.140, the education level of high school, group of age 34-41 years and the number of family members of 3-4 people. Consumer willingness to pay for the increase in rice prices gained majority of respondents are willing to pay that is majority of the respondents are willing to pay for $20 \%$ of the actual price and obtained that income, education, and age have strong relationship the willingness to pay which results of $\chi^{2}$ hit $>\chi_{\text {tabel }}^{2}$ then the decision is rejected $\mathrm{H}_{0}$, while the number of family members has no relationship to a willingness to pay because the results showed $\chi^{2}$ hit $>\chi_{\text {tabel }}^{2}$ so the decision to accept $\mathrm{H}_{0}$, indicating the higher of income level, education and age of the consumers, then the higher are willing to pay the increase in rice prices.

Keywords: Characteristics of Consumers, Willingness To Pay, Relations. 


\section{PENDAHULUAN}

Beras merupakan pangan pokok yang dikonsumsi oleh sebagian besar penduduk Indonesia sehingga masalah konsumsi beras dan pemenuhannya akan tetap menjadi hal penting dalam pembangunan ekonomi Indonesia. Dari sisi konsumen, lebih dari $90 \%$ penduduk Indonesia mengkonsumsi beras sebagai makanan pokok. (Bustaman, 2003), ini menunjukkan bahwa posisi beras sangat strategis sebagai penopang ketahanan pangan di Indonesia.

Di Provinsi Jambi, beras juga merupakan makanan pokok masyarakat dengan tingkat konsumsi pada tahun 2014 sebesar 93,5 Kg/Kapita/Tahun atau 11\% dari tingkat konsumsi beras di Indonesia, menunjukan bahwa ketergantungan masyarakat di Provinsi Jambi juga sangat tinggi dalam mengkosumsi beras baik di wilayah pedesaan maupun wilayah perkotaan.

Kota Sungai Penuh merupakan salah satu kota di Provinsi Jambi yang terbentuk dari hasil pemekaran Kabupaten Kerinci dengan luas wilayah 39.150 ha. Jumlah penduduk Kota Sungai Penuh pada tahun 2015 mencapai 86.220 jiwa (Badan Pusat Statistik Kota Sungai Penuh, 2015) dengan tingkat konsumsi beras pada tahun 2015 sebesar 99,8 Kg/Kapita/Tahun (Badan Ketahanan Pangan Kota Sungai Penuh, 2015). Tingkat konsumsi di daerah ini merupakan angka terbesar ke tiga setelah Kabupaten Kerinci dan Kabupaten Sarolangun.

Beragam jenis beras banyak beredar di pasaran Kota Sungai Penuh, baik pasar tradisional maupun pasar modern, sehingga dalam mengkonsumsi beras masyarakat dihadapkan dengan banyak pilihan. Harga beras selalu mengalami kenaikan setiap tahunnya baik itu beras kualitas I, II maupun III. Pada tahun 2014 harga beras kualitas I mengalami kenaikan dari Rp.12.906/Kg menjadi Rp.13.272/kg pada tahun 2015. Beras kualitas II naik dari harga Rp.10.043/kg menjadi Rp.11.076/kg dan beras kualitas III dari harga Rp.9.378/Kg naik menjadi Rp.10.211/Kg.

Kebutuhan konsumen dalam mengkonsumsi beras berbeda-beda antara satu dengan yang lainnya, salah satu faktor yang mempengaruhinya adalah karakteristik konsumen seperti pendapatan, pendidikan, usia dan jumlah anggota keluarga. Setiap orang atau keluarga mempunyai tingkat kebutuhan konsumsi beras yang dipengaruhi oleh faktor pendapatan, karena semakin besar pendapatan maka semakin tinggi pula tingkat kualitas beras yang dikonsumsinya. (Prayudi, 2000). Kemudian pendidikan juga dapat mempengaruhi kebutuhan konsumen. Apabila pendidikan konsumen tinggi maka konsumen akan lebih memilih barang-barang yang berkualitas baik (Setiadi, 2003). Menurut Sumarwan (2004) bahwa semua penduduk berapapun usianya adalah konsumen. Seseorang yang berumur relatif muda, akan lebih cepat menerima sesuatu yang baru. Selain itu, sebagian besar pengambilan keputusan pembelian beras dilakukan oleh ibu rumah tangga karena menurut Radam et al. (2010), bahwa perempuan lebih sadar kesehatan dibandingkan dengan laki-laki dan jumlah anggota keluarga 4 atau lebih cenderung sensitif terhadap harga dan enggan membayar produk yang tidak menjadi prioritasnya dan beras merupakan makanan utama yang harus dipilih dan dikonsumsi sesuai dengan kebutuhan keluarga.

Harga beras di Kota Sungai Penuh selalu mengalami kenaikan setiap tahunnya, berkisar 5\% 20\% (Dinas Perindustrian dan Perdagangan Kota Sungai Penuh, 2015). Banyaknya pilihan jenis beras dengan berbagai tingkatan harga membuat konsumen harus memilih jenis beras yang akan di konsumsinya. Karakteristik konsumen di Kota Sungai Penuh yang berbeda-beda mencerminkan besar kecilnya tingkat konsumsi dan kesediaan membayar terhadap kenaikan harga beras di Kota Sungai Penuh dan apabila kebutuhan konsumen dalam mengkonsumsi beras telah terpenuhi walaupun harga beras selalu mengalami kenaikan setiap tahunnya, maka konsumen akan bersedia membayar dari beras yang dikonsumsinya. Penelitian mengenai kesediaan membayar konsumen terhadap kenaikan harga beras ini dapat ditinjau dengan mengamati karakteristik konsumen seperti pendapatan, pendidikan, jumlah anggota keluarga, dan usia serta nilai kesediaan membayar (WTP) berdasarkan tingkatan kenaikan harga beras. Penelitian ini bertujuan untuk (1) mengidentifikasi karakteristik konsumen beras di Kota Sungai Penuh, (2) mengetahui nilai kesediaan membayar (WTP) terhadap kenaikan harga beras di Kota Sungai Penuh, dan (3) menganalisis hubungan antara karakteristik konsumen beras dengan kesediaan membayar (WTP) di Kota Sungai Penuh. 


\section{METODE PENELITIAN}

Penelitian ini dilaksanakan di Kota Sungai Penuh pada Kecamatan Pesisir Bukit yang diwakili dengan tiga desa yaitu Desa Koto Renah, Desa Koto Keras dan Desa Sungai Liuk. Pemilihan lokasi ini dilakukan secara sengaja (Purposive) dengan pertimbangan bahwa pemilihan kecamatan memenuhi kriteria yaitu konsumen beras yang mudah terpengaruh dengan perubahan harga beras dan berada didekat areal pasar. Penelitian ini menganalisis mengenai kesediaan membayar (Willingness To Pay) konsumen terhadap kenaikan harga beras di Kota Sungai Penuh yang dilihat dari karakteristik konsumen seperti pendapatan, pendidikan, jumlah anggota keluarga, dan usia serta nilai kesediaan membayar (WTP) berdasarkan tingkatan kenaikan harga beras seperti 5\%,10\%,15\% dan 20\% dari harga beras yang konsumen beli.

Data yang digunakan dalam penelitian ini adalah data primer dan data sekunder. Metode pengumpulan data yang digunakan dalam penelitian ini adalah dengan menggunakan teknik wawancara yaitu metode untuk mendapatkan informasi dengan cara bertanya langsung kepada konsumen, yang didasarkan pada pertanyaan atau kuisioner yang telah dipersiapkan sebelumnya.

Untuk menentukan ukuran sampel menggunakan rumus Taro Yamane atau Slovin dalam Riduan dan Akdon (2009) yaitu dalam ketentuan apabila sampel lebih dari 100 orang maka presisi dapat diambil $10 \%-15 \%$ atau $20 \%-25 \%$ atau lebih. Pada penelitian ini menggunakan presisi sebesar $11,5 \%$ sehingga diperoleh jumlah sampel sebanyak 71 orang responden yaitu ibu rumah tangga. Pada penelitian ini, teknik pengambilan sampel ditentukan dengan menggunakan metode penarikan sampel simple random sampling.

Untuk memperoleh gambaran karakteristik konsumen beras di Kota Sungai Penuh dilihat dari pendapatan, pendidikan, usia dan jumlah anggota keluarga serta nilai kesediaan membayar (WTP) konsumen terhadap kenaikan harga beras digunakan analisis deskriptif kuantitatif.

Untuk mengetahui kesediaan membayar (WTP) terhadap kenaikan harga beras menggunakan perhitungan persentase responden yang bersedia menerima kenaikan harga pada berbagai tingkat persentase kenaikan harga seperti 5\%,10\%,15\% dan 20\%. Selain itu, dari jumlah konsumen yang bersedia membayar diperoleh nilai kumulatif atau nilai rata - rata kesediaan membayar (WTP) konsumen terhadap kenaikan harga beras di Kota Sungai.

Untuk mengukur hubungan antara karakteristik konsumen dengan kesediaan membayar (WTP) dengan kenaikan harga beras di Kota Sungai Penuh menggunakan uji Chi-Square. Menurut Sugiyono (2013), Chi-Square merupakan suatu pendekatan yang digunakan untuk menguji hipotesis komparatif dua sampel bila datanya berbentuk nominal dan sampelnya besar. Menurut Rangkuti (2011), rumus pengujian statistik yang dipakai untuk Chi-Square adalah:

$$
\chi^{2}=\sum\left\{\frac{(O i j-e i j)^{2}}{E i j}\right\}
$$

Dimana: Oij = Nilai sel yang diamati (Observed)

Eij $\quad=$ Nilai sel yang diharapkan $($ Expected $)$

$\mathrm{r} \quad=$ Baris $($ Row $)$

$\mathrm{c} \quad=\operatorname{Kolom}($ Column $)$

Untuk mengukur kekuatan hubungan (2 variabel) dengan menggunakan koefisien kontingensi (Contingensi Coefficient) 2 x 4 pada tingkat kesediaan membayar (5\%,10\% 15\% dan 20\%). Menurut Rangkuti (2012), koefisien kontingensi dapat dihitung dengan menggunakan rumus:

$$
\mathrm{C}=\sqrt{\frac{\chi^{2}}{\chi^{2}+n}}
$$

Dimana : $\mathrm{C}=$ Nilai Koefisien

$\mathrm{n}=$ Jumlah frekuensi yang didapat dari pengamatan Koefisien Kontingensi

$\chi^{2}=$ Chi Square

Nilai koefisien maksimum dapat dihitung dengan menggunakan rumus :

$$
\mathrm{C}_{\text {maks }}=\sqrt{\frac{m-1}{m}}
$$


Setelah itu, untuk mengukur keeratan hubungan digunakan formulasi:

$$
r=\frac{C_{\text {hit }}}{C_{\text {maks }}}
$$

Dimana :

$\mathrm{r}=$ Koefisien keeratan hubungan (Derajat asosiasi atau defendensi)

$\mathrm{m}=$ Jumlah kolom atau baris pada tabel kontingensi dengan kategori sebagai berikut:

a. Derajat kecenderungan digolongkan lemah apabila nilai $C$ terletak antara 0-0,353

b. Derajat kecenderungan digolongkan kuat apabila nilai $\mathrm{C}$ terletak antara $0,353-0,707$

Untuk pengujian derajat hubungan antara karakteristik responden seperti pendidikan, pendapatan, usia dan jumlah anggota keluarga dengan terhadap kenaikan harga beras digunakan rumus sebagai berikut:

$$
t_{\text {hitung }}=r \sqrt{\frac{n-2}{1-r^{2}}}
$$

Dengan kriteria uji sebagai berikut:

Jika $t_{\text {hitung }} \leq t_{\text {tabel }}$ : tidak terdapat hubungan antara karakteristik responden dengan kesediaan membayar terhadap kenaikan harga beras (Ho $r=0)$

Jika $t_{\text {hitung }} \geq t_{\text {tabel }} \quad$ : terdapat hubungan antara karakteristik responden dengan kesediaan membayar terhadap kenaikan harga beras $(\mathrm{Ho} ; r \neq 0)$

\section{HASIL DAN PEMBAHASAN}

\section{Gambaran Umum Beras}

Gambaran umum beras adalah deskripsi mengenai beras yang dikonsumsi oleh responden di Kota Sungai Penuh yang dilihat dari jenis beras yang dikonsumsi, sumber informasi yang diperoleh oleh responden dalam mengkonsumsi beras, dan proses pembelian beras. Adapun penjelasan gambaran umum beras responden di Kota Sungai Penuh dijelaskan sebagai berikut :

Tabel 1. Gambaran Umum Beras Responden di Kota Sungai Penuh Tahun 2016

\begin{tabular}{clcc}
\hline No & \multicolumn{1}{c}{ Gambaran Umum Beras } & Keterangan & Persentase (\%) \\
\hline 1 & Jenis beras & Beras Ciwilis & 23 \\
2 & Sumber informasi & Diri sendiri & 38 \\
3 & Informasi yang diperoleh & Atribut fisik beras (Kepulenan, & 96 \\
& & aroma, rasa, warna) & 82 \\
4 & Keputusan pembelian beras & Tergantung situasi & 49 \\
5 & Pola frekuensi pembelian & 2 Kali & 97 \\
6 & Lama mengkonsumsi beras & $>2$ tahun & 83 \\
7 & Penyataan mengenai harga beras & Terjangkau & 69 \\
8 & Respon terhadap kenaikan harga & Membeli beras yang sama & 49 \\
& beras & 25 Kg-32 Kg & 75 \\
9 & Jumlah beras yang dibeli & Pasar tradisional & \\
10 & Lokasi pembelian beras & & \\
\hline
\end{tabular}

Tabel 1 menggambarkan beras yang dikonsumsi oleh responden di Kota Sungai Penuh, dimana sebagian besar responden mengkonsumsi jenis beras ciwilis yang menunjukkan bahwa jenis beras tersebut merupakan jenis beras kualitas dua yang banyak disukai karena memiliki rasa yang pulen dan harga terjangkau. 
Pada kategori sumber informasi utama mengenai beras yang diperoleh oleh responden berasal dari diri sendiri dimana faktor pengalaman akan berbagai atribut beras yang meliputi jenis, kualitas, rasa hingga harga beras memiliki peran dalam menentukan pilihan yang dibuat oleh responden. Besarnya kontribusi pengalaman dalam menentukan keputusan konsumen untuk menentukan jenis dan jumlah beras yang dikonsumsi per periode waktu dapat terjadi karena tingginya intensitas pembelian beras yang dilakukan oleh konsumen.

Dalam mengkonsumsi beras, responden harus mencari informasi terlebih dahulu terhadap jenis beras yang akan dikonsumsi oleh keluarga yang dimana dilihat dari atribut beras seperti kepulenan, aroma, rasa dan warna harus sesuai dengan keinginan dan selera keluarga responden. Selain itu dalam melakukan pembelian beras responden tidak memiliki terencana dan tergantung pada ketersediaan situasi beras di rumah tangga. Hal ini dapat dijelaskan bahwa responden tidak menaruh kekhawatiran akan kondisi ketersediaan beras sesuai dengan jenis dan kualitas beras yang dibutuhkan di tingkat pengecer karena beras yang diinginkan selalu tersedia di toko/warung/kios penjual sesuai dengan lokasi yang diinginkan oleh responden.

Dalam pola frekuensi pembelian beras, responden melakukan proses pembelian beras sebanyak 2 kali dalam satu bulan, menunjukkan bahwa alokasi dana untuk membeli beras sebagai kebutuhan utama tidak terlalu besar jika dibandingkan total pengeluaran per bulan yang dilakukan. Indikasi bahwa pengeluaran rumah tangga untuk membeli beras belum menjadi masalah yang mendasar dan dapat dilihat dari mayoritas responden melakukan proses pembelian beras yaitu sebanyak dua kali dalam satu bulan dan semakin banyak pola frekuensi pembelian beras yang dilakukan oleh responden, maka semakin banyak jumlah beras yang dikonsumsi oleh keluarga responden, kemudian responden telah terbiasa dengan jenis beras yang dikonsumsinya dan responden mengkonsumsi beras tersebut dalam waktu yang lama, sehingga responden memiliki banyak pengalaman terhadap jenis beras tersebut.

Harga beras di Kota Sungai Penuh masih dikategorikan terjangkau dibeli konsumen. Walaupun harga beras selalu mengalami kenaikan, responden tetap membeli beras karena beras merupakan kebutuhan keluarga yang harus dipenuhi setiap harinya. Responden akan tetap membeli beras yang sama karena jenis beras tersebut telah sesuai dengan kebutuhan keluarga sehingga tidak bisa digantikan dengan jenis beras lain. Tingkat konsumsi masyarakat Kota Sungai Penuh tergolong tinggi hingga mencapai $64 \mathrm{~kg}$ per bulan dan responden di Kota Sungai Penuh lebih mementingkan beras dibandingkan dengan lauk pauk. Rata-rata jumlah pembelian beras per keluarga per bulan oleh responden di Kota Sungai Penuh sebanyak $25 \mathrm{~kg}$ sampai $32 \mathrm{~kg}$ per bulannya. Responden membeli beras di pasar tradisional karena harga beras yang murah/ terjangkau dan jarak rumah responden dekat dengan pasar tradisional.

\section{Karakteristik Responden}

Tabel 2. Karakteristik Responden di Kota Sungai Penuh Tahun 2016

\begin{tabular}{|c|c|c|c|}
\hline No & Karakteristik & Keterangan & Persentase (\%) \\
\hline 1 & Pendapatan $(\mathrm{Rp} / \mathrm{B} \ln )$ & $\begin{array}{l}\text { Rp. } 900.000 \text { - Rp. } 17.040 .845 \\
\text { Rp. } 900.000 \text { - Rp. } 3.590 .140\end{array}$ & 24 \\
\hline 2 & Pendidikan & $\begin{array}{l}\text { SD - Perguruan Tinggi } \\
\text { SMA/Sederajat }\end{array}$ & 34 \\
\hline 3 & Usia (Tahun) & $\begin{array}{l}18-73 \\
34-41\end{array}$ & 25 \\
\hline 4 & Jumlah anggota keluarga (Orang) & $\begin{array}{l}1-12 \\
3-4\end{array}$ & 48 \\
\hline
\end{tabular}

Tabel 2 dapat diketahui bahwa responden tersebar pada berbagai tingkat pendapatan yang berbeda-beda, dimana mayoritas responden memiliki tingkat pendapatan keluarga per bulan sebesar 
Rp. 900.000 - Rp. 3.590 .140 dengan rentang pendapatan mulai dari Rp. 900.000 hingga lebih dari Rp.17.040.845. Dengan tersebarnya responden pada berbagai tingkat pendapatan tersebut, diharapkan variasi perilaku responden dalam penentuan kesediaan membayar terhadap kenaikan harga beras akan beragam sehingga dapat memberikan informasi yang aktual dari populasi yang diwakilinya.

Pada kategori pendidikan responden yang mengkonsumsi beras di Kota Sungai Penuh menyelesaikan pendidikan formal yang artinya semua responden tidak buta huruf. Responden yang pernah menempuh pendidikan SMA yang merupakan pendidikan mayoritas yang paling banyak ditempuh oleh responden. Semakin tinggi tingkat pendidikan maka semakin banyak pengetahuan dan pemahaman konsumen terhadap suatu produk, sehinga responden akan lebih banyak memilih mengenai beras yang dikonsumsi keluarga.

Terdapat sejumlah responden yang telah memasuki rentang usia tua, pada umumnya responden dalam kajian ini berada pada kelompok usia muda dan produktif. Pada kelompok usia muda sebagaimana mayoritas responden di Kota Sungai Penuh umumnya masih mengutamakan beras sebagai sumber karbohidrat utama dalam menu makanan yang dimiliki dan semakin tinggi usia responden maka semakin banyak pengalaman yang diperoleh responden dalam mengkonsumsi beras.

Jumlah anggota keluarga adalah semua orang yang berada dalam satu rumah atau berada diluar rumah yang menjadi tanggungan kepala keluarga. Banyaknya anggota keluarga yang menjadi tanggungan kepala keluarga akan mempengaruhi responden dalam kesediaan membayar terhadap kenaikan harga beras. Jumlah tanggungan keluarga mempengaruhi keputusan konsumen saat pembelian, semakin banyak jumlah anggota keluarga konsumen maka jumlah pembelian juga semakin tinggi, sehingga anggota keluarga berpengaruh besar terhadap keputusan pembelian (Rahardja dan Manurung, 2001).

\section{Kesediaan Membayar Responden terhadap Kenaikan Harga Beras}

Kesediaan membayar responden dilakukan untuk mengetahui berapa besar tingkatan harga yang bersedia dibayar oleh responden terhadap beras yang dikonsumsi apabila beras tersebut mengalami kenaikan harga. Salah satu tujuan yang hendak dicapai dari penelitian ini adalah melihat jumlah responden yang bersedia membayar apabila beras mengalami kenaikan harga. Oleh karena jenis dan kualitas beras yang dibeli konsumen cukup bervariasi yang bermuara pada perbedaan harga awal, maka WTP dalam penelitian ini diukur dari rata rata harga yang dibayarkan oleh konsumen tanpa membedakan jenis dan kualitas beras yang dikonsumsi. Dari wawancara terhadap 71 responden, semua responden bersedia membayar pada beberapa level, artinya tidak terdapat responden yang tidak bersedia membayar terhadap kenaikan harga beras. Perhitungan WTP dilakukan dengan menghitung persentase responden yang bersedia menerima kenaikan harga pada berbagai tingkat persentase kenaikan harga yang telah ditentukan seperti $5 \%, 10 \%, 15 \%$, dan $20 \%$ dari harga beras yang sebenarnya. Jumlah Responden yang bersedia membayar pada penelitian ini dapat dilihat pada Tabel 3 di bawah ini.

Tabel 3. Jumlah Responden yang Bersedia Membayar terhadap Kenaikan Harga Beras di Kota Sungai Penuh Tahun 2016

\begin{tabular}{ccc}
\hline $\begin{array}{c}\text { Tingkatan Kenaikan } \\
\text { Harga Beras }\end{array}$ & $\begin{array}{c}\text { Jumlah Responden yang Bersedia Membayar } \\
\text { (Orang) }\end{array}$ & $\begin{array}{c}\text { Persentase } \\
\text { (\%) }\end{array}$ \\
\hline $5 \%$ & 13 & 18 \\
$10 \%$ & 15 & 21 \\
$15 \%$ & 11 & 15 \\
$20 \%$ & 32 & 42 \\
Jumlah & $\mathbf{7 1}$ & $\mathbf{1 0 0}$ \\
\hline
\end{tabular}

Dari Tabel 3 di atas, dapat diketahui bahwa konsumen merasa sudah puas dengan pilihan jenis dan kualitas beras yang dikonsumsi saat ini, daya toleransi konsumen tersebut hanya mencapai 
kenaikan harga 5\%,10\% dan 15\% dari harga yang saat ini konsumen bayarkan karena dilihat dari kemampuan daya beli konsumen yaitu dilihat dari pendapatan dan apabila harga beras mengalami kenaikan hingga lebih dari 5\%,10\% dan 15\% maka konsumen akan membeli jenis beras lain yang harganya lebih murah. Sedangkan konsumen yang bersedia membayar beras jika harga beras mengalami kenaikan sebesar $20 \%$ menjelaskan bahwa konsumen tergolong konsumen fanatik yang bersedia untuk tetap membeli jenis dan kualitas beras yang saat ini dikonsumsi hingga kenaikan harga mencapai $20 \%$ bahkan lebih dari $20 \%$ dan dapat menunjukkan bahwa walaupun harga beras tersebut sudah mahal, konsumen masih sangat terikat pada komoditi beras yang biasa dikonsumsinya sebagai bahan pangan pokok keluarganya.

Selain itu, dari jumlah konsumen yang bersedia membayar dengan tingkatan harga 5\%, 10\%, $15 \%$ dan $20 \%$ diperoleh nilai kumulatif atau nilai rata - rata kesediaan membayar (WTP) konsumen terhadap kenaikan harga beras di Kota Sungai Penuh dapat dilihat pada tabel 4 di bawah ini.

\section{Tabel 4. Nilai Kumulatif Kesediaan Membayar (WTP) Konsumen terhadap Kenaikan Harga Beras di Kota Sungai Penuh Tahun 2016}

\begin{tabular}{ccc}
\hline $\begin{array}{c}\text { Tingkatan Kenaikan } \\
\text { Harga Beras }\end{array}$ & $\begin{array}{c}\text { Jumlah Konsumen yang Bersedia } \\
\text { Membayar (Orang) }\end{array}$ & Nilai Kumulatif (\%) \\
\hline $5 \%$ & 13 & 65 \\
$10 \%$ & 15 & 150 \\
$15 \%$ & 11 & 165 \\
$20 \%$ & 32 & 640 \\
\hline Jumlah & $\mathbf{7 1}$ & $\mathbf{1 . 0 2 0}$ \\
\hline Rata-Rata & & $\mathbf{1 4 , 4}$ \\
\hline
\end{tabular}

Dari Tabel 4 di atas, dapat diketahui bahwa mayoritas konsumen atau sebanyak 32 konsumen bersedia membayar pada tingkat harga sebesar $20 \%$ apabila beras mengalami kenaikan harga. Untuk konsumen yang bersedia membayar sebesar 5\%, 10\% dan 15\% menyatakan bahwa meskipun konsumen merasa sudah puas dengan pilihan jenis dan kualitas beras yang dikonsumsi saat ini, daya toleransi konsumen tersebut hanya mencapai kenaikan harga 5\%, 10\% dan 15\% dari harga yang saat ini konsumen bayarkan karena dilihat dari kemampuan daya beli konsumen yaitu dilihat dari pendapatan. Apabila harga beras mengalami kenaikan hingga lebih dari 5\% dan 10\% maka konsumen akan membeli jenis beras lain yang harganya lebih murah dari jenis beras yang biasa dikonsumsi dan apabila harga beras mengalami kenaikan lebih dari 15\% dari harga sebenarnya menyatakan bahwa konsumen akan memilih jenis beras lain dengan harga yang sama dari kenaikan harga beras sebesar $15 \%$ dan konsumen akan memilih jenis beras yang memiliki atribut dan kualitasnya lebih baik dari jenis beras yang biasa dikonsumsi oleh keluarga. Sedangkan konsumen yang bersedia membayar beras jika harga beras mengalami kenaikan sebesar 20\% menjelaskan bahwa konsumen tergolong konsumen fanatik atau konsumen yang bersedia membayar dan tetap membeli jenis dan kualitas beras yang selama in dikonsumsi oleh keluarga hingga kenaikan harga mencapai $20 \%$ dan ada peluang konsumen akan bersedia membayar lebih dari $20 \%$ dari harga yang biasanya konsumen bayarkan yang dapat menunjukkan bahwa walaupun harga beras tersebut sudah mahal, konsumen masih tetap membeli jenis beras yang biasa dikonsumsi karena konsumen sangat terikat pada komoditi beras yang biasa dikonsumsinya sehingga tidak bisa digantikan dengan jenis beras lain sebagai bahan pangan pokok keluarganya. Selain itu, dari jumlah konsumen yang bersedia membayar dengan tingkatan harga 5\%, $10 \%, 15 \%$ dan $20 \%$ diperoleh nilai kumulatif atau nilai rata - rata kesediaan membayar (WTP) konsumen terhadap kenaikan harga beras di Kota Sungai Penuh dapat dilihat pada Tabel 5 di bawah ini. 
Tabel 5. Nilai Kumulatif Kesediaan Membayar (WTP) Konsumen terhadap Kenaikan Harga Beras di Kota Sungai Penuh Tahun 2016

\begin{tabular}{ccc}
\hline $\begin{array}{c}\text { Tingkatan Kenaikan } \\
\text { Harga Beras }\end{array}$ & $\begin{array}{c}\text { Jumlah Konsumen yang Bersedia } \\
\text { Membayar (Orang) }\end{array}$ & Nilai Kumulatif (\%) \\
\hline $5 \%$ & 13 & 65 \\
$10 \%$ & 15 & 150 \\
$15 \%$ & 11 & 165 \\
$20 \%$ & 32 & 640 \\
\hline Jumlah & $\mathbf{7 1}$ & $\mathbf{1 0 2 0}$ \\
\hline Rata-Rata & & $\mathbf{1 4 , 4}$ \\
\hline
\end{tabular}

Dari Tabel 5 di atas, dapat diketahui bahwa rata-rata harga beras yang dikonsumsi oleh masyarakat di Kota Sungai Penuh sebesar Rp. 12.187 per Kg yang dimulai dari harga Rp. 9.375 per Kg sampai dengan harga Rp. 19.000 per Kg. Nilai kumulatif merupakan nilai rata-rata keseluruhan dari kesediaan membayar konsumen terhadap kenaikan harga beras. Secara kumulatif kesediaan membayar (WTP) konsumen beras di Kota Sungai Penuh adalah sebesar 14,4 \% atau setara dengan Rp. 1.755 dari harga rata-rata beras yang dibeli oleh konsumen sebesar Rp. 12.187 per Kg. Artinya, apabila harga beras mengalami kenaikan hingga 14,4\% maka konsumen beras di Kota Sungai Penuh masih tetap bersedia membayar dan tetap mengkonsumsi jenis beras dengan atribut yang saat ini mereka konsumsi. Hal ini juga menunjukkan bahwa masyarakat di Kota Sungai Penuh masih sangat terikat pada jenis beras yang selama ini dikonsumsinya karena beras sebagai bahan pangan pokok yang tidak bisa digantikan dengan bahan makanan lain sehingga berapapun kenaikan harga beras tersebut, masyarakat akan tetap bersedia membayar. Menurut Yuliyanti (2011) menyatakan bahwa dampak dari kenaikan harga beras pada prinsipnya tidak terlalu berpengaruh pada konsumsi masyarakat, karena beras merupakan kebutuhan pokok yang paling utama. Jadi mahal atau tidak, beras tetap akan dibeli masyarakat, tetapi jenis dan harga beras yang dibeli akan berbeda.

Sesuai dengan penelitian Aklima Dhiska Suwanda (2012) mengenai kesediaan membayar beras analog bahwa responden akan tetap bersedia membayar walaupun harga beras mengalami kenaikan. Responden masih bersedia membayar beras dengan harga yang lebih tinggi sampai mencapai $\mathrm{Rp}$. 22.610 per 800 gram. Hal ini dikarenakan beras merupakan kebutuhan utama masyarakat diberbagai daerah di Indonesia, dan selain sebagai kebutuhan pokok, berbagai jenis beras juga baik untuk kesehatan khususnya beras analog, sehingga sampai kapanpun responden akan tetap mengutamakan beras sebagai makanan pokok utama dalam memenuhi kebutuhan keluarga.

Dalam hal ini pun dapat dibandingkan dengan penelitian Perhepi Komda Jambi (2016) mengenai perilaku, preferensi dan kepuasan konsumen terhadap beras di Provinsi Jambi yang menunjukkan bahwa sejumlah responden tergolong konsumen fanatik dimana mereka bersedia untuk tetap membeli jenis dan kualitas beras yang saat ini dikonsumsi hingga kenaikan harga $20 \%$. Artinya, apabila harga beras mengalami kenaikan hingga 20\% maka konsumen beras di wilayah Provinsi Jambi masih akan tetap mengkonsumsi jenis dengan atribut yang saat ini mereka konsumsi.

\section{Hubungan Karakteristik Konsumen dengan Kesediaan Membayar terhadap Kenaikan Harga Beras}

Penelitian ini menganalisis apakah terdapat hubungan antara karakteristik responden seperti pendapatan, pendidikan, usia dan jumlah anggota keluarga dengan kesediaan membayar responden terhadap kenaikan harga beras dimana tingkat kenaikan harga beras tersebut telah ditentukan seperti $5 \%, 10 \%, 15 \%$ dan $20 \%$ dari harga beras yang sebenarnya.

\section{Hubungan antara Pendapatan dengan Kesediaan Membayar terhadap Kenaikan Harga Beras}

Hubungan antara pendapatan dengan kesediaan membayar terhadap kenaikan harga beras dapat dilihat pada Tabel 6 berikut : 
Tabel 6. Tabel Kontingensi Tingkat Pendapatan dengan Kesediaan Membayar terhadap Kenaikan Harga Beras

\begin{tabular}{|c|c|c|c|c|c|}
\hline \multirow[t]{2}{*}{ Pendapatan } & \multicolumn{4}{|c|}{ Tingkat Bersedia Membayar } & \multirow[t]{2}{*}{ Jumlah } \\
\hline & $5 \%$ & $10 \%$ & $15 \%$ & $20 \%$ & \\
\hline Rendah & 7 & 10 & 6 & 8 & 31 \\
\hline Tinggi & 6 & 5 & 5 & 24 & 40 \\
\hline Jumlah & 13 & 15 & 11 & 32 & 71 \\
\hline
\end{tabular}

Berdasarkan Tabel 6, dapat diketahui bahwa rata-rata pendapatan responden yaitu sebesar Rp. 5.568.310 ber bulan. Pendapatan responden terdiri dari pendapatan rendah dan pendapatan tinggi, dimana pendapatan rendah merupakan pendapatan yang berada di bawah Rp. 3.500 .000 per bulan dan pendapatan tinggi di atas Rp. 3.500 .000 per bulan. Responden yang berpendapatan rendah mayoritas bersedia membayar dengan tingkat kesediaan membayar sebesar $10 \%$ yaitu sebanyak 10 responden (14\%) sedangkan responden yang berpendapatan tinggi mayoritas bersedia membayar dengan tingkat kesediaan membayar sebesar $20 \%$ yaitu sebanyak 24 responden $(33 \%)$.

Hasil uji Chi-Square diperoleh nilai $\chi_{\text {hit }}^{2}$ sebesar 8,90> $\chi_{\text {tabel }}^{2}(\alpha=5 \%, \mathrm{db}=3)$ sebesar 7,815 maka keputusannya tolak $\mathrm{H}_{0}$. Hal ini berarti terdapat hubungan yang signifikan antara pendapatan dengan kesediaan membayar terhadap kenaikan harga beras. Dari analisis di atas dapat disimpulkan bahwa semakin tinggi pendapatan responden maka semakin bersedia responden membayar terhadap kenaikan harga beras karena beras merupakan bahan makanan pokok yang harus dikonsumsi setiap hari, sehingga apabila beras yang dikonsumsinya mengalami kenaikan, maka responden akan bersedia membayar jenis beras yang dikonsumsinya dan tidak mengganti jenis beras dengan jenis beras lain.

Hasil penelitian ini konsisten dengan hasil penelitian terdahulu yang dilakukan oleh Aklima Dhiska Suwanda (2012) mengenai analisis kesediaan membayar konsumen terhadap harga beras analog dengan menggunakan metode Chi-Square diperoleh nilai Asymp. Sig. (2-sided) pada output uji Chi-Square menunjukkan angka 0,33 yang lebih kecil dari taraf nyata yang digunakan yaitu $(0,067<$ $0,10)$. Nilai tersebut menunjukkan bahwa karakteristik pendapatan berhubungan signfikan dengan kesediaan membayar beras analog.

Hubungan antara Pendidikan dengan Kesediaan Membayar terhadap Kenaikan Harga Beras

Hubungan antara pendidikan dengan kesediaan membayar terhadap kenaikan harga beras dapat dilihat pada Tabel 7 berikut.

Tabel 7.Tabel Kontingensi Tingkat Pendidikan dengan Kesediaan Membayar terhadap Kenaikan Harga Beras

\begin{tabular}{cccccc}
\hline \multirow{2}{*}{ Pendidikan } & \multicolumn{4}{c}{ Tingkat Bersedia Membayar } & \multirow{2}{*}{ Jumlah } \\
\cline { 2 - 5 } & $\mathbf{5 \%}$ & $\mathbf{1 0 \%}$ & $\mathbf{1 5 \%}$ & $\mathbf{2 0 \%}$ & \\
\hline Rendah & 8 & 9 & 6 & 6 & 29 \\
Tinggi & 5 & 6 & 5 & 26 & 42 \\
\hline Jumlah & $\mathbf{1 3}$ & $\mathbf{1 5}$ & $\mathbf{1 1}$ & $\mathbf{3 2}$ & $\mathbf{7 1}$ \\
\hline
\end{tabular}

Berdasarkan Tabel 7, dapat diketahui bahwa pendidikan responden terdiri dari pendidikan rendah sampai dengan tamat SMP dan pendidikan tinggi SMA ke atas. Responden yang berpendidikan rendah mayoritas bersedia membayar dengan tingkat kesediaan membayar sebesar $10 \%$ yaitu sebanyak 10 responden (14\%) sedangkan responden yang berpendidikan tinggi mayoritas bersedia membayar dengan tingkat kesediaan membayar sebesar $20 \%$ yaitu sebanyak 26 responden (36\%). 
Hasil uji Chi-Square dipeoleh pada nilai $\chi_{\text {hit }}^{2}$ sebesar 11,91 $>\chi_{\text {tabel }}^{2}(\alpha=5 \%$, db $=3)$ sebesar 7,815 maka keputusannya tolak hipotesis. Hal ini berarti terdapat hubungan antara pendidikan dengan kesediaan membayar terhadap kenaikan harga beras. Dari analisis di atas dapat disimpulkan bahwa semakin tinggi seseorang menempuh pendidikan, maka semakin banyak pengetahuan mengenai beras yang dikonsumsinya baik dari gizi maupun kualitas karena responden akan lebih banyak mencari informasi mengenai beras yang dikonsumsinya, sehingga dalam kesediaan membayar, responden tersebut telah mengetahui mana beras yang baik untuk dikonsumsi mana yang buruk untuk dikonsumsi oleh keluarga.

Hasil penelitian ini sejalan dengan hasil penelitian terdahulu yang dilakukan oleh Joni Murti Mulyo (2010) mengenai perilaku konsumen pada pembelian beras bermerek dengan menggunakan metode Chi-Square diperoleh nilai $\chi_{\text {hitung }}^{2} 7,538>$ dari pada $\chi_{\text {tabel }}^{2} 3,841$ sehingga menerima hipotesis. $\mathrm{Hal}$ ini menjelaskan bahwa terdapat hubungan yang nyata antara tingkat pendidikan dengan kesediaan membayar pada beras bermerek.

\section{Hubungan antara Usia dengan Kesediaan Membayar terhadap Kenaikan Harga Beras}

Hubungan antara usia dengan kesediaan membayar terhadap kenaikan harga beras dapat disajikan pada Tabel 8 berikut :

Tabel 8. Tabel Kontingensi Tingkat Usia dengan Kesediaan Membayar terhadap Kenaikan Harga Beras

\begin{tabular}{cccccc}
\hline Usia & \multicolumn{4}{c}{ Tingkat Bersedia Membayar } & Jumlah \\
\cline { 2 - 5 } & $\mathbf{5 \%}$ & $\mathbf{1 0 \%}$ & $\mathbf{1 5 \%}$ & $\mathbf{2 0 \%}$ & \\
\hline$<43$ & 8 & 10 & 6 & 9 & 33 \\
$\geq 43$ & 5 & 5 & 5 & 23 & 38 \\
\hline Jumlah & $\mathbf{1 3}$ & $\mathbf{1 5}$ & $\mathbf{1 1}$ & $\mathbf{3 2}$ & 71 \\
\hline
\end{tabular}

Berdasarkan Tabel 8, dapat diketahui bahwa rata-rata usia konsumen yaitu berusia 43 tahun. usia responden pada usia yang lebih tua tetap bersedia membayar pada berbagai level kenaikan harga sebanyak 23 responden (32\%) sedangkan responden pada usia ini muda mayoritas bersedia membayar dengan tingkat kesediaan membayar sebesar $10 \%$ yaitu sebanyak 10 responden $(14 \%)$.

Hasil uji uji Chi-Square diperoleh nilai $\chi_{\text {hit }}^{2}$ sebesar $8,35>\chi_{\text {tabel }}^{2}(\alpha=5 \%, \mathrm{db}=1)$ sebesar 3,841 maka keputusannya tolak $\mathrm{H}_{0}$. Hal ini dapat disimpulkan bahwa terdapat hubungan antara usia dengan kesediaan membayar terhadap kenaikan harga beras, karena semakin tinggi usia responden maka semakin banyak pengalaman responden terhadap beras yang dikonsumsinya sehingga responden akan tetap bersedia membayar apabila harga beras mengalami kenaikan. Responden pada tingkat usia lebih tua, dalam mengkonsumi beras cenderung membutuhkan banyak pertimbangan karena memiliki banyak pengalaman terhadap beras yang dikonsumsinya dan sudah sesuai dengan kebutuhan keluarga sehingga tetap mengkonsumsi jenis beras yang sama walaupun harga beras yang dikonsumsinya mengalami kenaikan harga yang tinggi.

Kondisi ini juga terjadi dengan hasil penelitian terdahulu yang dilakukan oleh Alfianah Nuraini Putri (2009) hubungan antara usia dengan preferensi merek motor dengan menggunakan metode ChiSquare diperoleh nilai $\chi^{2}$ sebesar 0,035 dan nilai $\alpha$ sebesar 0,05 yang menyatakan $(0,035<0,05)$ sehingga $\mathrm{H}_{0}$ ditolak sehingga dapat disimpulkan bahwa terdapat hubungan antara usia terhadap preferensi merek bermotor.

\section{Hubungan antara Jumlah Anggota Keluarga dengan Kesediaan Membayar terhadap Kenaikan Harga Beras}

Hubungan antara jumlah anggota keluarga dengan kesediaan membayar terhadap kenaikan harga beras dapat dilihat pada Tabel 9 berikut : 
Tabel 9. Tabel Kontingensi Jumlah Anggota Keluarga dengan Kesediaan Membayar terhadap Kenaikan Harga Beras

\begin{tabular}{cccccc}
\hline Anggota Keluarga & \multicolumn{4}{c}{ Tingkat Bersedia Membayar } & Jumlah \\
\cline { 2 - 5 } & $\mathbf{5 \%}$ & $\mathbf{1 0 \%}$ & $\mathbf{1 5 \%}$ & $\mathbf{2 0} \%$ & \\
\hline$<5$ & 7 & 9 & 6 & 21 & 43 \\
$\geq 5$ & 6 & 6 & 5 & 11 & 28 \\
\hline Jumlah & $\mathbf{1 3}$ & $\mathbf{1 5}$ & $\mathbf{1 1}$ & $\mathbf{3 2}$ & $\mathbf{7 1}$ \\
\hline
\end{tabular}

Berdasarkan Tabel 9, dapat diketahui bahwa rata-rata jumlah anggota keluarga responden terdiri dari 5 anggota keluarga dan dalam penelitian ini jumlah anggota keluarga responden terdiri dari $<5$ anggota keluarga dan $\geq 5$ anggota keluarga. Responden yang memiliki jumlah anggota keluarga $\geq 5$ mayoritas bersedia membayar dengan tingkat kesediaan membayar sebesar $20 \%$ yaitu sebanyak 21 responden (21\%) sedangkan responden yang memiliki jumlah anggota keluarga $\geq 5$ mayoritas bersedia membayar dengan tingkat kesediaan membayar sebesar 20\% yaitu sebanyak 11 responden (15\%). Tabel 2 menjelaskan jumlah anggota keluarga mayoritas sebnayak 3-4 sebanyak 48\% dengan rata-rata sebanyak 5 orang.

Hasil uji Chi-Square diperoleh nilai $\chi_{\text {hit }}^{2}$ sebesar $0,76<\chi_{\text {tabel }}^{2}(\alpha=5 \%, \mathrm{db}=3)$ sebesar 3,841 diperoleh kesimpulan terima $\mathrm{H}_{0}$. Hal ini berarti tidak terdapat hubungan antara jumlah anggota keluarga dengan kesediaan membayar terhadap kenaikan harga beras. Keadaan ini sejalan dengan hasil penelitian dari Aklima Dhiska Suwanda (2012) mengenai analisis kesediaan membayar konsumen terhadap harga beras analog dengan menggunakan metode Chi-Square diperoleh 0.763 yang berarti lebih besar dari taraf nyata yang digunakan $(0,763>0,10)$. Jadi dapat disimpulkan bahwa tidak terdapat hubungan antara karakteristik jumlah anggota keluarga dengan kesediaan membayar beras analog, hal ini tidak terlepas dari peluang pasar beras analog yang berpotensi sebagai alternatif pangan pokok yang lebih sehat, sehingga tidak membatasi konsumen baik keluarga kecil, keluarga besar, atau bahkan belum berkeluarga.

\section{KESIMPULAN}

Karakteristik konsumen terdiri dari pendapatan, pendidikan, usia dan jumlah anggota keluarga. Konsumen akan bersedia membayar walaupun harga beras mengalami kenaikan karena konsumen masih sangat terikat pada jenis beras yang biasa dikonsumsinya sebagai bahan pangan pokok keluarganya. Dari hasil uji Chi-Square diperoleh bahwa tingkat pendapatan, pendidikan dan usia memiliki hubungan yang kuat dengan kesediaan membayar konsumen terhadap kenaikan harga beras sedangkan untuk jumlah anggota keluarga tidak memiliki hubungan dengan kesediaan membayar terhadap kenaikan harga beras.

\section{UCAPAN TERIMAKASIH}

Penulis mengucapkan terimakasih kepada Dekan Fakultas Pertanian Universitas Jambi dan Ketua Program Studi Agribisnis Fakultas Pertanian Universitas Jambi serta Perhimpunan Ekonomi Pertanian Indonesia yang telah memfasilitasi pelaksanaan penelitian ini, ucapan terimakasih kepada Dinas Perindusrian dan Perdagangan Kota Sungai Penuh yang sangat membantu serta memberikan data bagi penulis, sehingga penulis dapat menyelesaikan artikel ini.

\section{DAFTAR PUSTAKA}

Akdon dan Riduan. 2009. Rumus dan Data dalam Analisis Statistika. Penerbit Alfabeta. Bandung. 
Badan Ketahanan Pangan. 2015. Tingkat Konsumsi Pangan Penduduk Kota Sungai Penuh. Badan Ketahanan Pangan Kota Sungai Penuh. Jambi.

Badan Pusat Statistika. 2015. Kota Sungai Penuh Dalam Angka 2015. Badan Pusat Statistik Kota Sungai Penuh. Kota Sungai Penuh.

Bustaman, A. D. 2003. Analisis Integrasi Pasar Beras di Indonesia. Jurnal Skripsi. Institut Pertanian Bogor. Bogor.

Daulay MD. 2012. Analisis Proses Keputusan Pembelian Konsumen Untuk Membayar (Willingness to Pay) Mie Instan Sayur di Serambi Botani, Botani Square. Bogor. Skripsi. Fakultas Ekonomi dan Manajemen.Institut Pertanian Bogor. Bogor.

Dhiska, Aklima, S. 2012. Analisis Kesediaan Membayar (Willingness To Pay) Beras Analog di Serambi Botani. Jurnal Skripsi. Fakultas Ekonomi dan Manajemen Institut Pertanian Bogor. Bogor.

Dinas Perindustrian dan Perdagangan. 2015. Harga Beras Kota Sungai Penuh. Dinas Perindustrian dan Perdagangan Kota Sungai Penuh. Kota Sungai Penuh.

Manurung dan Rahardja, P. 2001. Teori Ekonomi Makro Suatu Pengantar. Lembaga Penerbit Fakultas Ekonomi Universitas Indonesia. Jakarta.

Murti, Joni, M. 2010. Perilaku Konsumen Pada Pembelian Beras Bermerk Di Kabupaten Jember Dan Faktor Yang Mempengaruhinya. Skripsi. Jurusan Sosial Ekonomi Pertanian Fakultas Pertanian Universitas Jember. Jember.

Nugroho, Setiadi, J. 2003. Perilaku Konsumen. Kencana. Jakarta.

Nuraini, Alfianah, P. 2009. Hubungan Antara Usia Dengan Preferensi Merek Motor. Jurnal Skripsi. Fakultas Ekonomi Universitas Jenderal Soedirman. Jakarta.

Perhepi Komda Jambi. 2016. Perilaku, Preferensi dan Kepuasan Konsumen Terhadap Beras di Provinsi Jambi. Jambi.

Prayudi, S. 2000. Pembangunan dan Pendapatan Desa. Ghalia Indonesia. Jakarta.

Radam , Yacob MR, Bee TS, Selamat J. 2010. Consumer's Perceptions, Attitudes dan Willingness to Pay towards Food Products with "No Added MSG" Labelling. International Journal of Marketing Studies.

Rangkuti, F. 2011. Riset Pemasaran. Gramedia Pustaka Umum. Jakarta.

Simonson, I. \& Drolet, A. 2003 . Anchoring Effects on Consumers' Willingness To Pay and Willingness To Accept. Research Paper Series No. 1787, Stanford Graduate School of Business. California.

Sugiyono. 2010. Statistika Untuk Penelitian. Alfabeta. Bandung.

Sumarwan U. 2004. Perilaku Konsumen Teori dan Penerapannya dalam Pemasaran. PT Ghalia Indonesia. Bogor. 